\title{
Emanation Study of Gas Radon on the Ancient Cuexcomate Geyser in Puebla City, Mexico
}

\author{
J. A. MONARCA SERRANO ${ }^{1}$, M. DE JESÚS CIRILO', C.VÁZQUEZ- \\ LÓPEZ ${ }^{*}$, B. E. ZENDEJAS-LEAL ${ }^{2}$, J. I. GOLZARRI ${ }^{3}$, G. ESPINOSA ${ }^{3}$
}

${ }^{1}$ Facultad de Ingeniería, Colegio de Geofísica. Benemérita Universidad Autónoma de Puebla

${ }^{2}$ Departamento de Física. Centro de Investigación y de Estudios Avanzados del Instituto Politécnico Nacional Ave. IPN 2508, Col. San Pedro Zacatenco. 07360, Ciudad de México.

${ }^{3}$ Instituto de Física. Universidad Nacional Autónoma de México. Circuito de la Investigación Científica, Ciudad Universitaria. 04520, Ciudad de México.

*Email: cvlopez@fis.cinvestav.mx

Published online: August 08, 2016,

The Author(s) 2016. This article is published with open access at www.chitkara.edu.in/publications

Abstract Radon measurements were collected over a period of nine months in the area of the ancient Cuexcomate geyser, in Puebla City. For measuring radon, the passive method of nuclear tracks in solids was used, using polycarbonate CR-39 as radiation sensitive material. Radon concentrations varied in strong anti-correlation with the rainfall intensity. And are lower compared to other locations, in concordance with the stratigraphic composition, as travertine and deposits of volcanic origin, corresponding to the geyser chemical composition and the active environment in the north part of the Trans-Mexican Volcanic Belt with an andesitic and basalt composition.

Keywords: Radon detection, Cuexcomate volcano, Radon and rainfall.

\section{INTRODUCTION}

Puebla State is within the Trans-Mexican Volcanic Belt that extends from the Pacific Ocean to the Gulf of Mexico, giving rise to several volcanoes and mountains of various altitudes. The state consists of igneous basic rock extrusive from the Cenozoic age. The upper valley and near the town, deposits of limestone tufa, which have been caused by chemical sediments from the numerous sulfur hot springs that exist are from the early quaternary. Within 10

Journal of Nuclear

Physics, Material Sciences, Radiation and Applications Vol-4, No-1, August 2016 pp. $277-284$ 
Monarca Serrano, J.A. m depth is a layer of travertine, determined by geophysical studies [4], which de Jesús Cirilo, M. is related to the aforementioned sulphurous activity.

Vázquez- López, C.

The Cuexcomate is an extinct fountain. A calcariferous geyser that used to Zendejas-Leal, B.E.

Golzarri, J.I.

Espinosa, G. throw its waters at considerable heights, and then fell spilled to go to mingle with the waters of Atoyac river, leaving in its path carbonate lime bringing in solution, forming thick crusts of lime stone (tuff limestone) around the mouth of the geyser. Igneous rocks (granite, pegmatite, rhyolite, tuff, etc.), formed after cooling and solidification of magma or molten rock inside the earth, often contain radioactive elements distributed within very fine crystalline particles. But the radioactivity is not exclusive to these rocks because sometimes deposits of rocks formed by the accumulation of sediment or sedimentary (conglomerates, clays, sandstone, mudstone, limestone, etc.), being porous and permeable mineral staying well $\mathrm{U}$ and Th leading to significant deposits of radioactive minerals. Metamorphic rocks (marble, quartzite, metamorphic schist, gneiss, slate, etc.) formed at high pressures from igneous or sedimentary rocks tend to keep the content of radioactive minerals of the original rock. Phosphate deposits (sedimentary rock composed of mineral apatite group) and carbon (hydrocarbons) have special consideration as both phosphates as hydrocarbons housed well huge cations $\mathrm{U}$ and Th.[3]

The Cuexcomate is an inactive geyser in Puebla City, Puebla State, Mexico. In Figure 1 the location of Cuexcomate is shown. [8]

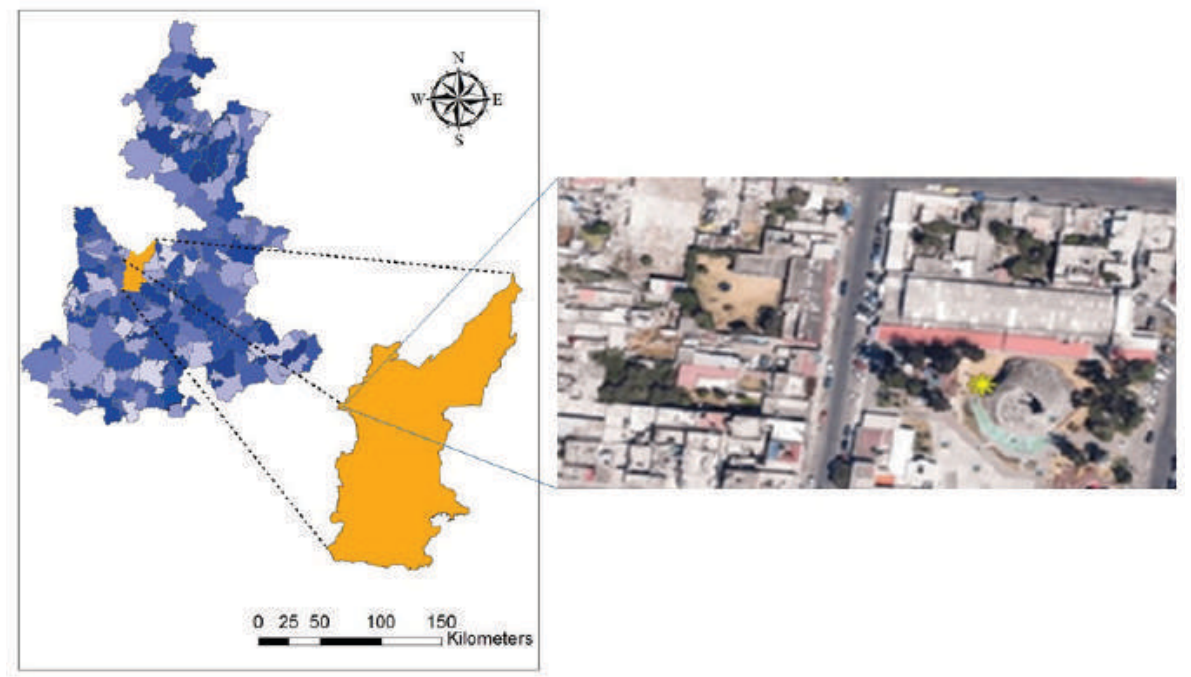

Figure 1: Location of the Cuexcomate. Puebla City is in yellow color. Puebla State is in blue color. The right side picture shows a satellite view of the Cuexcomate region. 
It stands at $13 \mathrm{~m}$ with a diameter of $23 \mathrm{~m}$, and mouth between 4 and $8 \mathrm{~m}$. It is thought to be the biggest geyser on Earth. In Figure 2a picture of the Cuexcomate is shown.

Historically it has been cited that the geyser was formed before the 1064 eruption of the Popocatepetl, an active volcano and the second highest peak in Mexico, which likely activated geothermal spring circulation that cut upward through Mesozoic limestone and deposited the geyser and the springs around it. The geyser's rock composition is $99 \%$ calcite, differing thus from typical silica sinter deposits.

Cuexcomate has been called 'The Smallest Volcano of the World' because of the popular belief that it was indeed a volcano, based only on the shape of the structure. [1] Today, there is a metal spiral staircase that allows tourists to descend into the excavated interior of the structure, where cultural events are even performed. In Figure 3 a view of the entrance is shown. he name is from Nahuatl for "clay pot" or "place to keep". location: $19^{\circ} 04^{\prime} 14.7^{\prime \prime} \mathrm{N}$ $98^{\circ} 14^{\prime} 05.7^{\prime \prime} \mathrm{W}$. [3].

As is known, the study of the emission of Radon from the subsoil is a very powerful tool for geologists, as indicator of certain rocks composition. There exists a correlation of the emission with the geological maps, which gives rise to the lithology of the place.

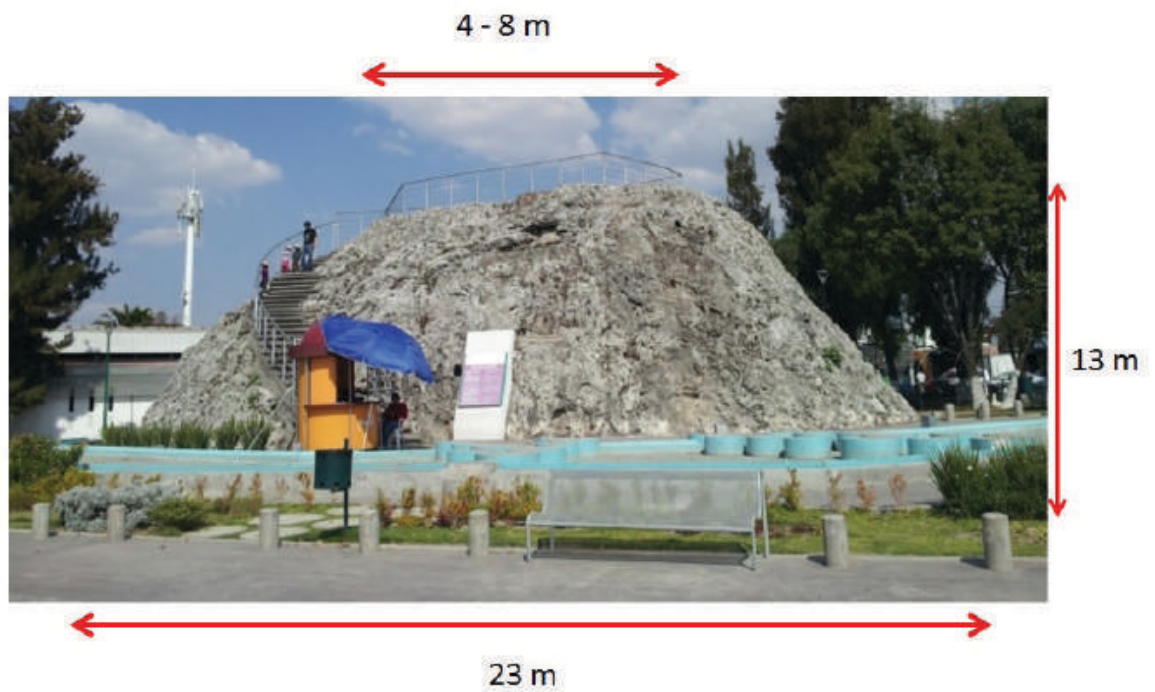

Figure 2: Picture of the Cuexcomate and external dimensions.
Emanation Study of Gas Radon on the Ancient Cuexcomate Geyser in Puebla City, Mexico

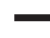


Monarca Serrano, J.A. de Jesús Cirilo, M.

Vázquez- López, C.

Zendejas-Leal, B.E.

Golzarri, J.I.

Espinosa, G.

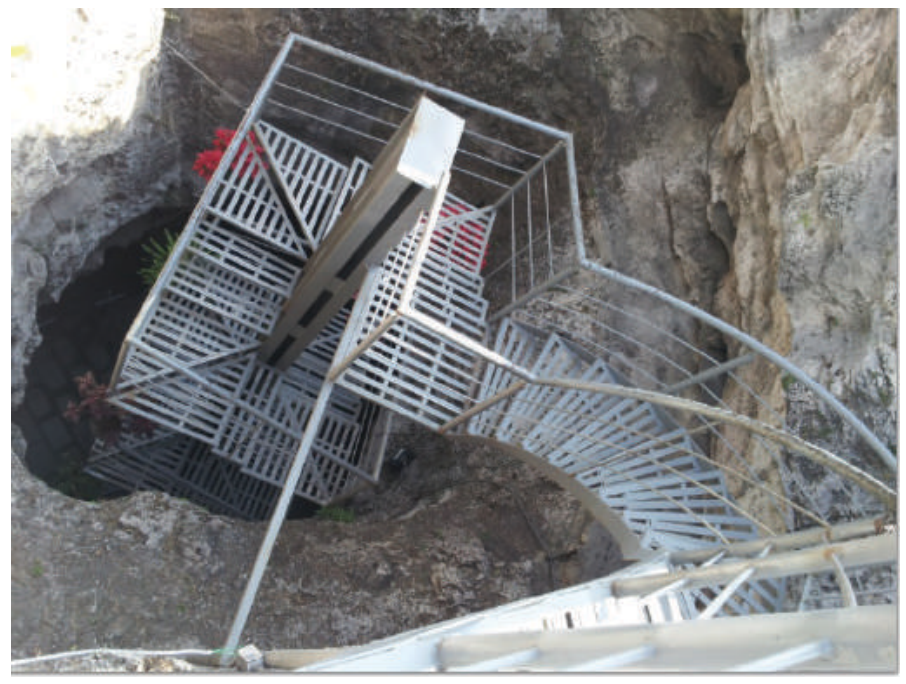

Figure 3: View of the entrance to the Cuexcomate cave, from above.

\section{EXPERIMENTAL}

The nuclear tracks methodology was used to measure the Radon activity in the Cuexcomate. CR-39, $600 \mu \mathrm{m}$ thick polycarbonate (Landauer ${ }^{\circledR}$ ) was used as the detection material. The CR-39 was cut by the manufacturer automatically by a $\mathrm{CW} \mathrm{CO}$ laser beam into chips of size $9 \mathrm{~mm} \times 18 \mathrm{~mm}$. To develop the alpha track a one-step chemical etching in $\mathrm{KOH}, 6.25 \mathrm{M}$ at $60^{\circ} \mathrm{C} \pm 1{ }^{\circ} \mathrm{C}$ for 18 hours was used. [2] The etched tracks were counted by a Counting and Analysis Digital Image System (CADIS), developed at the Institute of Physics, UNAM. [5] All theprocedures were optimized step by-step.

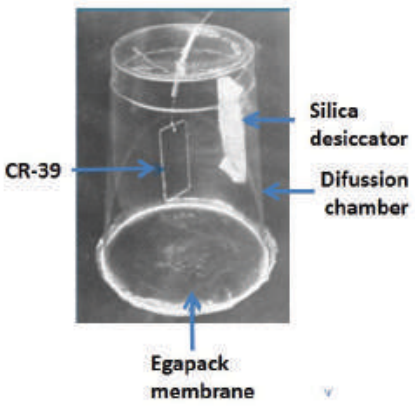

Figure 4: Detector device for measuring Rn activity in the atmosphere inside the Cuexcomate cave. 


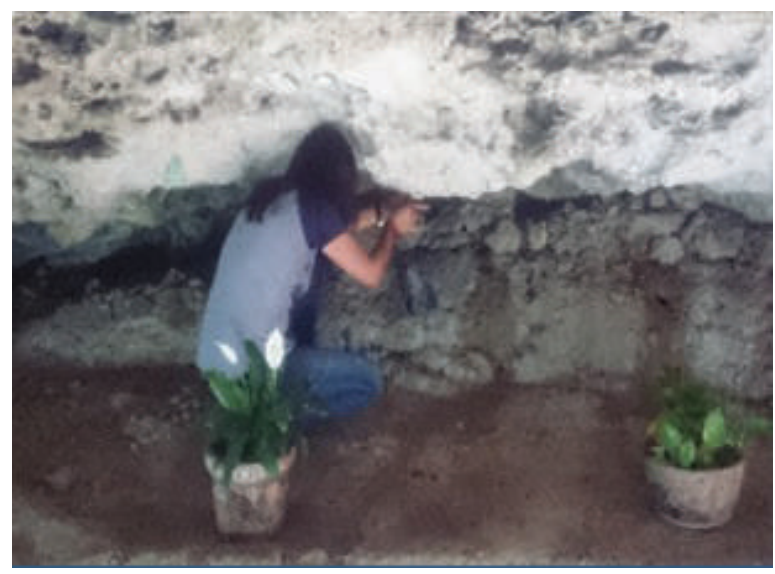

Emanation Study of Gas Radon on the Ancient Cuexcomate Geyser in Puebla City, Mexico

Figure 5: Installing a Rn detector device, inside the Cuexcomatecave.

For the inner part of the geyser, truncated conical diffusion chambers were used. [6] In Figure 4, a picture of this device is shown. For this device, the Rn activity in $\mathrm{Bq} / \mathrm{m}^{3}$ is given by Equation 1:

$$
\text { Activity }=\rho / A t
$$

Where $\rho$ is the tracks density in (Tracks) $\left(\mathrm{cm}^{-2}\right), A$ is the calibration factor, that was obtained at the Oak Ridge National Laboratory facilities, resulting $\mathrm{A}=$ 5 (Tracks) $\left(\mathrm{cm}^{-2}\right) /\left(\mathrm{Bqm}^{-3} / \mathrm{month}\right)$, and $\mathrm{t}$ is the exposure time in months. In this work a month was used as exposure time.

In Figure 5, one of the authors is installing a Rn detector device inside the crater, out of reach of visitors.

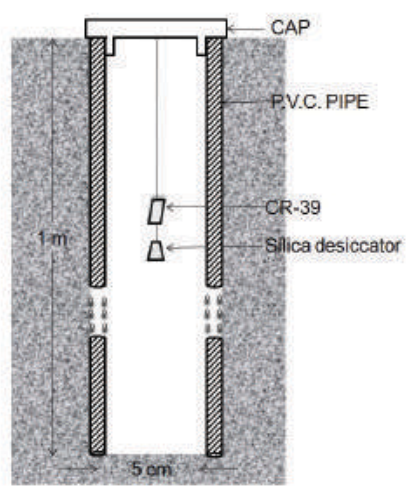

Figure 6: Device for measuring Rn influence underground outside the Cuexcomate cave. 
Monarca Serrano, J.A. de Jesús Cirilo, M.

Vázquez- López, C.

Zendejas-Leal, B.E.

Golzarri, J.I.

Espinosa, G.

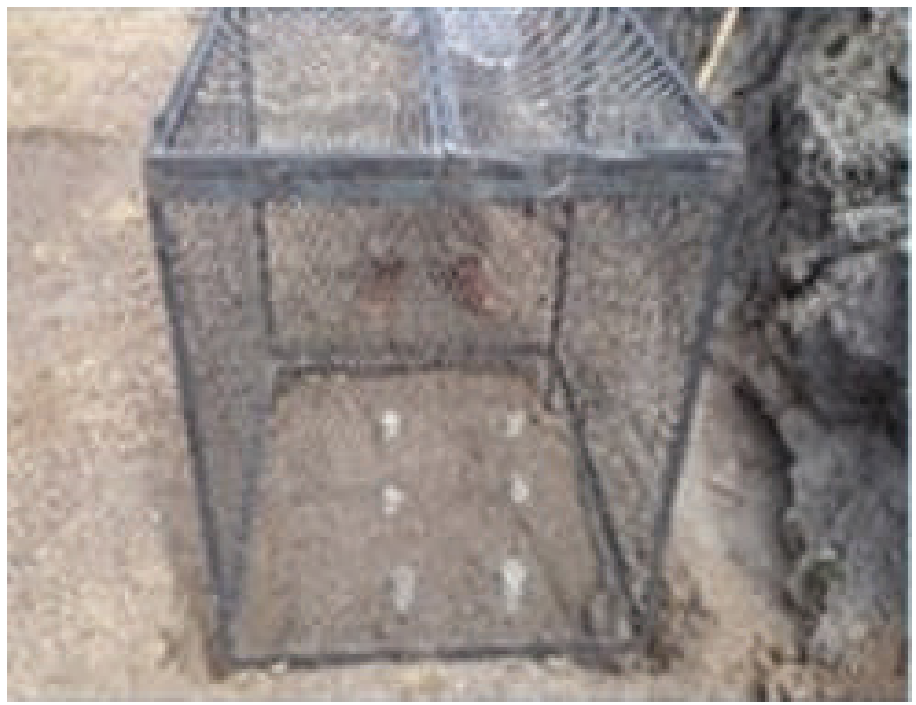

Figure 7: Buried detector devices outside the Cuexcomate cave. A protection cage was also installed.

The detector device for underground measurements isshown in Figure 6. The cap is removable in order to change easily the CR-39 and the desiccator monthly. In Figure 7, a picture of the buried devices is shown. A protection cage was installed in order to avoid people vandalism.

The rainfall data were obtained from the meteorological station of Comision Nacional del Agua, in Puebla City, San CristobalTulcingo. The location is: 19.5292N 98.1962W, at $5.2 \mathrm{~km}$ distance towards NE of Cuexcomate.

\section{RESULTS AND DISCUSSION}

In Figure 8 the evolution of Rn activity inside the Cuexcomate crater is shown, during the period August - December 2015, and January - April, 2016. The blue color curve refers to the daily rainfall in mm, starting on July $1^{\text {st }}, 2015$. An increase in the Rn activity is observed during dry months.

In Figure 9 the evolution of the tracks density and rainfall underground outside the Cuexcomate cave is shown. It is also observed a clear correlation between the dry season and an increase in Radon activity. The reason of this behavior is that Radon may diffuse through air filled pores in the sediment by virtue of the inherent kinetic energy. Radon can migrate up to a meter a day in dry sediments through such movement, but much less when water fills the pores. [7] 


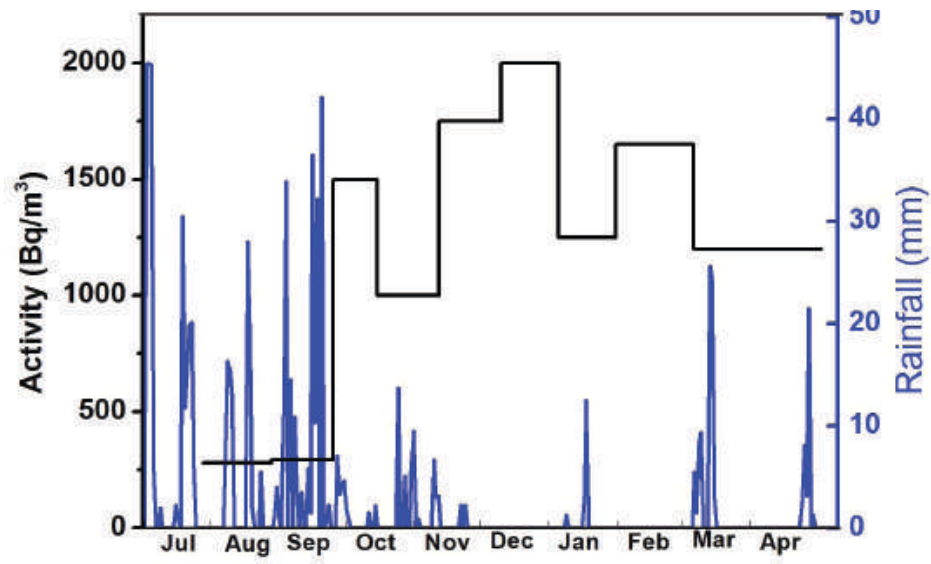

Emanation Study of Gas Radon on the Ancient Cuexcomate Geyser in Puebla City, Mexico

Figure 8: Evolution of Radon activity (black solid curve, left scale) and daily rainfall (blue peaks, right scale) during 315 days.

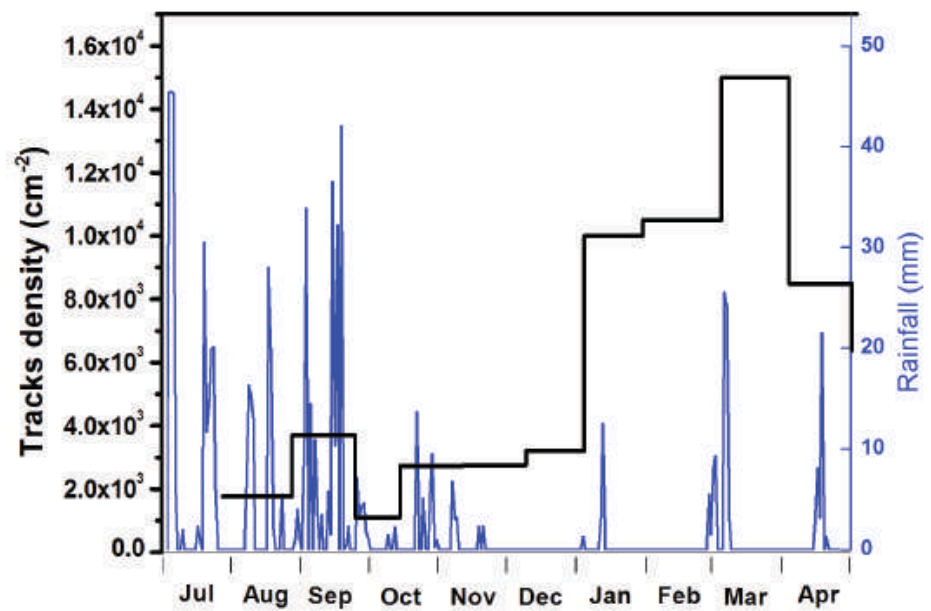

Figure 9: Underground measurements of tracks density (black solid lines, left scale) and daily rainfall (blue lines, right scale) during 315 days.

\section{CONCLUSIONS}

Concentrations of radon in the Cuexcomate geyser region are correlated with the rainfall, at time scales of months. Rain causes a decrease in radon concentrations because it reduces the permeability of the surface sediment. High rainfall saturates the epikarst preventing radon emission into the cave 
Monarca Serrano, J.A. atmosphere and into the upper region of soil. During dry weather the radon de Jesús Cirilo, M. concentration increases inside the cave atmosphere, reaching values above the Vázquez- López, C. EPA permissible for indoor wells. However, these values are not risky for Zendejas-Leal, B.E. $\quad$ tourist visitors.

Golzarri, J.I.

Espinosa, G.

\section{ACKNOWLEDGEMENTS}

The authors acknowledges the interest and kindles for this work of the authorities of La Junta Auxiliar de La Libertad, Puebla City, particularly José Enrique Guerrero Romero, President, and José Guadalupe Gómez Báez, Coordinator.

The rainfall data were provided by Comisión Nacional del Agua (CONAGUA, México). We thank specially the interest of Mr. Germán Sierra Sánchez, director local de la Comisión Nacional del Agua. This work was partially supported by Dirección General del Personal Académico de la UNAM, Project UNAM-DGAPA-PAPIIT-IN103316.

\section{REFERENCES}

[1] Beraldi-Campesi, Hugo. Cuexcomate: from the smallest volcano to the biggest geyser on earth. Cordilleran Section - 108th Annual Meeting (29-31 March). Geological Society of America. Vol. 44, No. 3, p. 57. (2012).

[2] Espinosa, G. andGammage, R.B. Measurements Methodology for Indoor Radon Using Passive Track Detectors. Applied Radiation and Isotopes. 44, 719 (1993). http://dx.doi.org/10.1016/0969-8043(93)90138-Z

[3] López S. J., Hernández J.C. D., and Castillo R. J. Estudios Geológicos y Geofísicos de Riesgos Naturales.Organizador:Carlos Suárez, Geos, Vol. 27, No. 1, Avancessobrelaevaluación del peligro por hundimiento mediante métodos geofísicos en la Colonia LaLibertad, Puebla, México.(2007) http://research.omicsgroup.org/index.php/Cuexcomate.

[4] López S., Ferrari L. Avances en el conocimiento de la Faja Volcánica

[5] Patent pending. Inventors: Enrique Cabrera and Guillermo Espinosa. IFUNAM. (2016).

[6] Rickards, J., GolzarriJ.I., Vázquez-LópezC., and EspinosaG., Radon Detection in Conical Diffusion Chambers: Monte Carlo Calculations and Experiment, AIP Conference Proceedings Vol.1671: pp 020011-1-020011-5. ISBN 978-0-73541318-4.(2015).

[7] Whittlestone, S., James, and Barnes, C. The Relationship between Local Climate and Radon Concentrations in the Temple of Baal, Jenolan Caves, Australia. Helictite, 38(2): 39-44.(2003).

[8] http://research.omicsgroup.org/index.php/Cuexcomate. 